\title{
A Case of Nasal Schwannoma Coexisting with Epidermal Cyst
}

\author{
Tae Kyung Koh ${ }^{1}$, Woo Yong Bae ${ }^{1}$ and Seo-Hee Rha ${ }^{2}$ \\ ${ }^{I}$ Departments of Otolaryngology-Head and Neck Surgery, ${ }^{2}$ Pathology, College of Medicine, Dong-A University, Busan, Korea
}

\author{
표피 낭과 공존하는 비강 내 신경초종 1예 \\ 고태경 ${ }^{1} \cdot$ 배우용 $^{1} \cdot$ 나서희 $^{2}$ \\ 동아대학교 의과대학 이비인후-두경부외과학교실, ${ }^{1}$ 병리학교실 ${ }^{2}$
}

\author{
Received May 7, 2013 \\ Revised June 19,2013 \\ Accepted July 1, 2013 \\ Address for correspondence \\ Woo Yong Bae, MD \\ Departments of Otolaryngology- \\ Head and Neck Surgery, \\ College of Medicine, \\ Dong-A University, \\ 26 Daesingongwon-ro, Seo-gu, \\ Busan 602-715, Korea \\ Tel +82-51-240-5423 \\ Fax $+82-51-253-0712$ \\ E-mail doncamel@dau.ac.kr
}

Schwannomas of the sinonasal tract are very rare benign neoplasm, which can arise from nerve sheath containing Schwann cells. Epidermal cysts are also rarely present in nasal cavity. They are thought to be congenital lesion associated with various craniofacial disorders or arise as a result of implantation of epidermal cells into the deeper dermal element. Several cases of the nasal schwannoma or epidermal cyst have been reported repectively, however nasal schwannoma with epidermal cyst never has been reported yet. We report the first case of nasal schwannoma which is coexists with epidermal cyst at the superior turbinate of the nasal cavity.

Korean J Otorhinolaryngol-Head Neck Surg 2013;56:787-90

Key Words Epidermal cyst · Nasal schwannoma $\cdot$ Superior turbinate.

\section{서 론}

신경초종은 신경초 세포에서 기원하는 양성 종양으로 비강 이나 부비동에서 기원한 경우는 $4 \%$ 정도로 드물다. 대부분 사 골동과 비강을 동시에 침범하는 것과 상악동이 가장 흔하며, 비강, 접형동, 전두동 순으로 빈발하고, 희귀하게 비중격에서 도 발생할 수 있다. ${ }^{1)}$ 표피 낭은 Keratin cyst 또는 sebaceous cyst로 불리기도 하며, 발생학적 이상에서 기인하거나, 외상 및 수술 등에 의해 표피세포가 진피로 이전하여 발생할 수 있다. 표피 낭은 피부 부속기나 샘이 없는 케라틴 층상 편평상피세 포로 되어 있으며 비강 내 발생은 드물게 알려져 있다. ${ }^{2}$ 하지만 현재까지 표피 낭과 신경초종이 함께 발견된 예는 두개 내에서 표피 낭종 제거 후 신경초종의 진행 및 발견, 상대되는 측의 동 시 발견만이 알려져 있으며, 비강 내의 동시 발견은 알려진 바 없다. ${ }^{34)}$ 또한 신경초종의 상비갑개 기원에 대해서도 지금까지 보고된 바 없었다. 이에 저자들은 66세 여자 환자에서 상비갑 개에서 기원되었으며, 조직학적으로 표피 낭과 함께 존재하는
신경초종으로 확인된 1예를 치험하였기에 문헌 고찰과 함께 보 고하는 바이다.

\section{증 례}

66세 여자 환자로 우측 비폐색을 주소로 내원하였다. 이학 적 검사상 우측 상비도에 매끈한 표면의 낭성 종물이 발견되 었으며(Fig. 1A), 부비동 전산화단층촬영 소견상 우측 비강 내 $3 \mathrm{~cm}$ 의 종물이 관찰되었다. 종물의 겉 표면은 조영되고, 종물 내에는 음영이 감소된 소견이 관찰되었고(Fig. 2), 일반적인 비 강내 폴립보다는 낭성, 종양성 병변이 의심되어 비내시경 하 종물 절제술을 계획하였다. 전신마취 하에서 비내시경 하 종물 절제술을 시행하였으며, 낭성 종물이 우측 상비갑개에서 기원 하여, 중비갑개를 내측으로, 상비갑개를 외측으로 편위시키는 것이 관찰되었다. 주변 점막 및 골 침범 소견은 관찰되지 않았 다. 우측 비강 쪽으로 보이는 낭벽을 sickle knife로 비점막과 함께 절개한 후 ethmoid 겸자로 조심스럽게 제거하였고, 노란 
빛이 도는 치즈양의 내용물은 낭성 조직과 함께 병리조직검사 를 시행하였다. 술 후 조직검사 결과에서는 S-100 단백면역 염 색상 양성 반응을 보여 신경초종을 시사하였으며, 노란색의
내용물은 다층의 케라틴 층이 있었으며, 피부 부속기는 관찰되 지 않아서 표피 낭에 합당한 소견을 보였다(Fig. 3). 환자는 현 재 술 후 5 개월째로 정기적인 외래 추적관찰 중이며, 재발 소

Fig. 1. Preoperative endoscopic finding of the right nasal cavity revealed a pinkish, smooth surfaced mass (A). Postoperative endoscopic finding shows no mass lesion (B).
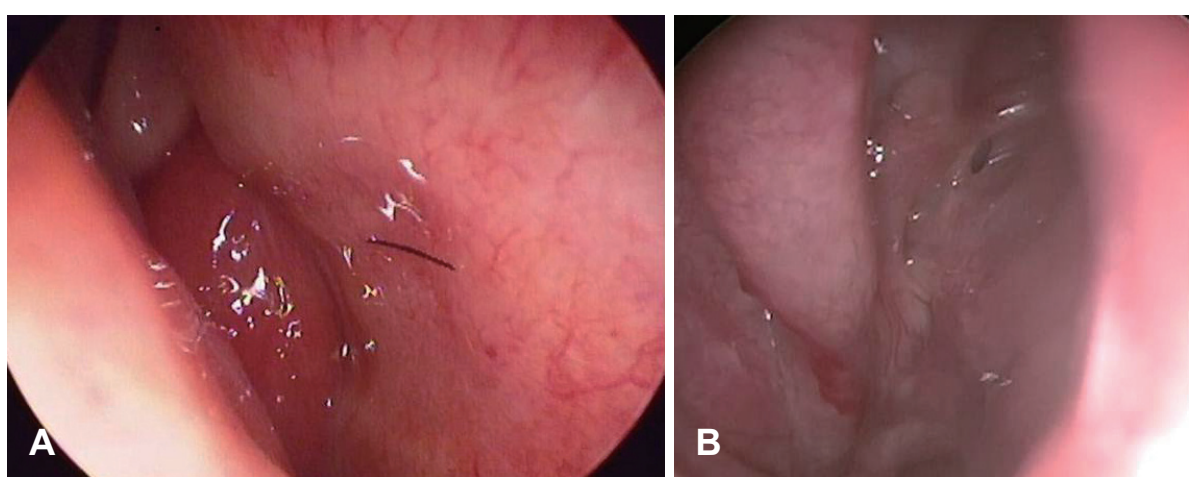

Fig. 2. Axcial (A) and coronal CT (B) scan showing about $3 \mathrm{~cm}$-sized mass lesion in the right nasal cavity.
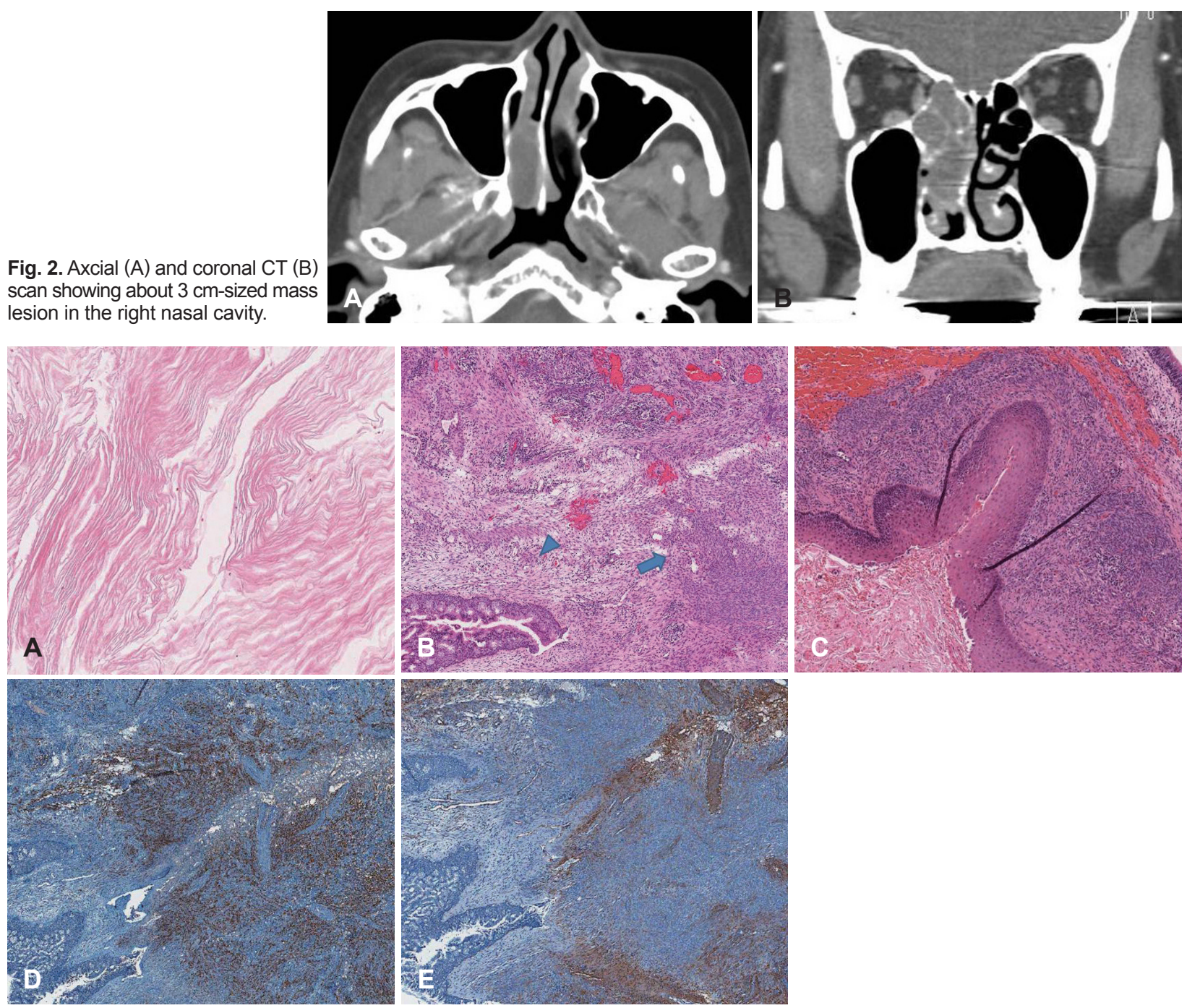

Fig. 3. Microscopic findings. The cystic content is multi-layered scales of keratin, suggesting epidermal cyst $(H \& E, \times 200)(A)$. The Nasal mucosa shows an ill-defined subepithelial mass composed of alternating hypocellular (arrowhead) and hypercellular (arrow) area of spindle cells $(H \& E, \times 50)(B)$. A submucosal schwannoma composed of compact bundles of spindle cell, surrounding the epidermal cyst (left lower). The pseudostratified columnar epithelium of nasal cavity is seen on the right upper corner $(\mathrm{H \& E}, \times 50)(\mathrm{C})$. The spindle tumor cells are positive for S-100 (immunohistochemistry, $\times 20)(D)$ and negative for smooth muscle actin (immunohistochemistry $\times 40)(E)$ showing Schwann cell differentiation. 
견은 없는 상태이다(Fig. 1B).

\section{고 찰}

신경초종과 표피 낭은 발생 기원부터 다른 양성 종양이다. 신경초종은 말초 신경집의 신경초 세포에서 기원하는 것으로 알려졌으며, 1942년 DelRio-Hortega에 의해 신경초종으로 불 리게 되었다. ${ }^{1)}$ 시각과 후각 신경에는 신경초 세포층이 존재하 지 않아 신경초종이 발생하지 않으며 두경부 영역중 비강 내 에 발생하는 신경초종은 $4 \%$ 의 빈도로 드물다. ${ }^{1.5}$ 비강 내 신경 초종은 삼차신경과 연관된 사골동 기원의 발생, 교감 및 부교 감 신경 기원의 발생이 알려져 있다. ${ }^{6}$ 표피 낭은 선천적으로 상 피층에 둘러싸인 표피의 분화과정과 연관되거나 후천적으로 외상이나 수술적 조작에 의한 상피세포가 상피 내층으로 이식 되어 발행하는 것으로 알려져 있다." 주로 비강 내 표피 낭은 선천적 기원으로 알려져 있으며, 피부 부속기가 없으면서 섬유 성 피낭과 상피세포로 둘러싸여 있으며, 가장 흔한 호발 부위 는 전두동과 사골동으로 알려져 있다.,8)

임상적 증상은 신경초종의 경우 종물의 분포나 지배 신경의 기원에 따라 다양하지만, 주로 종물에 의한 압박감 혹은 통증, 비폐색, 비루, 후각 이상 등을 호소할 수 있다.8) 하지만 표피 낭 은 서서히 자라는 양성 종물로 방치될 경우 외비변형, 이차감 염, 두개 내 합병증을 나타내고, 초기에는 특이 증상이 없다. ${ }^{9}$ 본 증례의 경우 환자는 우측 비강의 비폐색 이물감 외에 다른 증상은 호소하지 않았다. 이학적 검사 상 비강후방에 피막에 잘 싸여진 비특이적인 낭성의 종물이 관찰되었다.

방사선학적 소견은 신경초종과 표피 낭 모두 비특이적이다. 신경초종의 경우 전산화단층촬영 상 종물 내 주변의 낭성 조 직과 구분되는 고밀도의 조영 증강을 보이는 것이 특징이며, 표피 낭은 전산화단층촬영 상 경계가 분명하고, 경화된 변연과 주변 구조물로 확장된 소견 및 비조영 증강의 양상을 보인다. 표피 낭으로 인해 골미란이 있거나, 두개 내 침범이 있을 경우, 비중격의 확장, 미간의 연조직성 음영, 계관 돌기의 이분화, 맹 공의 개방 및 크기 증가 등의 소견을 나타낸다. ${ }^{10)}$ 따라서 전산 화단층촬영은 양성과 악성의 구분 및 종괴의 범위를 판단하 는 데는 도움이 되나 진단을 내리는 데는 충분한 정보를 주지 못한다. 본 증례의 전산화단층촬영 소견은 우측 비강 내에 종 물 변연의 조영증강과 종물 내 비조영 증강의 소견이 보이는 $3 \mathrm{~cm}$ 가량의 종물이 관찰되었다. 이학적 소견 및 방사선학 적 소견은 비특이적이었으며, 진단을 위해 조직학적 절제 및 생검이 필요하였다.

조직병리학적 소견은 신경초종의 경우 S-100 단백면역염색 에서 양성 반응을 보이고, $\mathrm{H \& E}$ 염색 상에서 Antoni type $\mathrm{A}$ 와
$\mathrm{B}$ 가 혼재된 소견을 나타내는 것이 특징이다. Antoni A형은 고밀도의 방추형세포가 주위 결합조직과 잘 배열되어 있으며, 핵은 책상 배열을 이루고 내부에 verocay body 분포를 특징 으로 하고, Antoni B형은 상대적으로 퇴행성의 변화와 함께 엉 성한 점액질의 간질 조직 분포를 보이며 출혈성 괴사가 동반되 기도 한다. ${ }^{11)}$ 표피 낭은 $\mathrm{H \& E}$ 염색 상 편평형 상피로 덮혀 있고 케라틴 층을 나타내며 피부 부속기를 포함하지 않는 것을 특 징으로 한다. ${ }^{7}$ 본 증례의 경우, 종물은 병리조직학적 검사 상 S100 단백면역 염색 상 양성 반응을 나타내어 신경초종으로 진 단되었으며, 노란색의 내용물은 피부 부속기 없이 다층의 케 라틴 층을 보이는 표피 낭에 합당한 소견을 보여, 신경초종과 표피 낭이 함께 존재하는 것으로 확인되었다. 본 증례에서 발 생 기원이 다른 신경초종과 표피 낭이 함께 존재하는 것을 설 명하기는 어렵다. 하지만, 첫 번째 가설은 비강 내 발생한 신경 초종에 외상에 의한 호흡 상피세포의 종물 내 이식으로 발생 했을 가능성이 있으며, 두 번째 가설로는 발생과정 이상으로 선천적으로 존재하던 표피 낭 주변으로 신경초종이 발생하였 을 가능성이 있다. 또한 이 종물은 비폐색 이외의 특이 증상이 없었던 것으로 보아 교감 또는 부교감 신경 기원보다는 삼차 신경 분지에서 기원한 신경초종으로 생각되어진다.

치료는 신경초종의 경우 방사선치료에 저항성이 있어 수술 적 절제술이 원칙이다. 비강 내 신경초종은 단발성이며 피막화 되어 있어, 비내시경을 통한 수술적 제거술의 결과가 좋은 것 으로 알려져 있다. ${ }^{12}$ 표피 낭의 경우 종물의 범위나 합병증에 따라 수술 방법이 선택되나, 비내시경을 이용한 방법이 효율적 이고 안전한 방법으로 알려져 있다. ${ }^{8)}$ 본 증례의 경우 비내시경 과 전산화단층촬영 소견 상 종물이 두개 내 침범, 외비 변형 등 을 일으키지 않고 비강 내에 국한되어 있음을 확인한 상태로 비내시경적인 종물의 완전절제가 가능하였다. 비강 내 신경초 종과 표피 낭 모두 발생한 예가 많지 않아 진단과 치료방법이 아직 확실히 정립된 바 없다. 종물의 병변 범위가 국소적일 경 우 비내시경을 통해 기원을 확인하고 절제술을 통한 병리학적 인 확진이 종물의 진단과 치료의 최소 침습적인 방법이라 생 각한다.

\section{REFERENCES}

1) Pasic TR, Makielski K. Nasal schwannoma. Otolaryngol Head Neck Surg 1990;103(6):943-6.

2) Ciappetta $P$, Artico M, Salvati M, Raco A, Gagliardi FM. Intradiploic epidermoid cysts of the skull: report of 10 cases and review of the literature. Acta Neurochir (Wien) 1990;102(1-2):33-7.

3) Saito A, Sugawara T, Watanabe R, Akamatsu Y, Mikawa S, Seki H. Evolution of vestibular schwannoma after removal of epidermoid cyst of the same location: case report. Neurol Med Chir (Tokyo) 2009; 49(10):495-8.

4) Zhao AS, Lee HJ, Jyung RW. Concomitant, contralateral vestibular schwannoma and epidermoid cyst. Laryngoscope 2010;120 Suppl 4: 
S220

5) Choi AY, Kim JS, Yoon SW, Hong YO. A case of schwannoma arising from the sphenoid sinus. Korean J Otorhinolaryngol-Head Neck Surg 2011;54(1):89-92.

6) Hegazy HM, Snyderman CH, Fan CY, Kassam AB. Neurilemmomas of the paranasal sinuses. Am J Otolaryngol 2001;22(3):215-8.

7) Jangam DK, Singh M, Shenoy S. Epidermoid cyst (cholesteatoma) of the maxillary sinus: report of rare case and review. URJD 2011;1(1): 49-53.

8) Bang JH, Han JH. A case of endoscopic approach of epidermoid cyst arising in the inner surface of nasal bone. Korean J Otolaryngol-Head
Neck Surg 2000;43(5):545-8.

9) Cho SH. A case of epidermoid cyst of the glabella. Korean J Otolaryngol 1975;18(4):89-92.

10) Frodel JL, Larrabee WF, Raisis J. The nasal dermoid. Otolaryngol Head Neck Surg 1989;101(3):392-6.

11) Park SK, Lee SC, Park CK, Kim SH. A case of huge neurilemmoma of the ethmoid sinus invading intracranial fossa. Clin Otolaryngol 1992;3(1):135-9

12) Choe H, Jun YJ, Cho WS, Kim TH. A case of schwannoma of the nasal cavity mimicking olfactory neuroblastoma. Korean J Otolaryngol-Head Neck Surg 2007;50(6):548-51. 